\title{
A handbook on
}

Legal Languages and the quest for linguistic equality in South Africa and beyond

Zakeera Docrat Russell H Kaschula Monwabisi K Ralarala

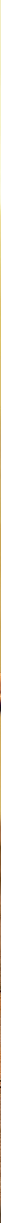




\section{SOUTH AFRICA'S LEGAL PRACTITIONERS AND JUDICIAL OFFICERS \\ Language qualifications and competencies}

\section{Legislative language requirements for legal practitioners}

In the case law presented in Chapter 7 it was evident that African languages can be used as languages of record in the first instance and be translated for appeal and review processes. This was evident from cases of State v Damoyi (2004), State v Matomela (1998) and State v Damani (2016). For this to happen, legal practitioners and judicial officers would need to be linguistically competent in the languages of the province in which the court is seated. The same principle and line of reasoning applies for a bilingual or multilingual language of record policy to be existent in each of the provinces: there would need to be linguistically competent legal practitioners. By 'linguistically competent', we refer to LLB graduates who have also mastered, at university level, an official language other than, or in addition to, English. This line of reasoning is advanced from a point of practicality given that the majority of South Africans speak an African language or Afrikaans, or both as their mother tongue. Linguistic competency in a language other than English can readily be achieved where mother tongue African language and Afrikaans speaking students are able to learn their mother tongue at an intellectual university level. The same applies to second language speakers who already have a strong command of a second language and pursue this language at university level. The language competence required for the LLB curriculum is discussed in Chapter 9.

In Chapter 2, we advanced the fourth tier of language planning, namely opportunity planning (Antia, 2017); and how, through language planning, incentives must be created to implement the legislation and language policy successfully. University language policies thus have to relate to the broader legislative framework of disciplines, such as the legal system, where job creation is key. 
In the introduction of Chapter 1 we noted that, during Apartheid, language requirements were legislated for attorneys in the Attorneys Act (1979). These language requirements were in accordance with the official languages at the time, namely English, Afrikaans and Latin. With the transition to a constitutional democracy, the legislation was amended in the form of the Attorneys Amendment Act 115 of 1993 (1993a). It was anticipated that the Attorneys Amendment Act (1993a) would be reflective of the then 'new' constitutional language provisions of Section 6 of the Constitution, which were already in existence in the Interim Constitution (1993). This was not the case, and no African language requirements were included.

Chapter 1, Sections 2 to 24 of the Attorneys Amendment Act (1993a), concerns the qualifications, admission and removal of attorneys from the roll. Language requirements for admission are absent from these provisions; specifically, Sections 4 and 15 solely concern admission to the attorneys' profession. Sections $13 \mathrm{~B}$ and 14 concern the completion of training in legal practice management and practical examinations. Section 2 of the Attorneys Amendment Act (1993a) concerns the duration of service under articles. No listed provisions include language requirements or training of any sorts.

Similar to the Attorneys Amendment Act (1993a), the Admission of Advocates Act, 74 of 1964 was amended post-Apartheid, resulting in the Admission of Advocates Amendment Act, 55 of 1994 (1994b). The earlier Admission of Advocates Act (1964) recognised English, Afrikaans and Latin as language requirements at university level prior to admission to the Bar of Advocates. This changed with the amendment and the change was highlighted in the purpose of the Act (1994b):

[To] Amend the Admission of Advocates Act (1964) to abolish the requirement that must be complied with by persons in respect of the Latin language in order to be admitted to practice as advocates; and to delete or substitute certain obsolete words and expressions; and to amend laws of the former Republics of Transkei, Bophuthatswana and Venda with regard to the admission of advocates; and to provide for matters connected therewith.

There was a clear abolishment of the Latin language requirement. However, no insertion of an African language requirement occurred. The English and Afrikaans language requirements were later also removed from the Act. Essentially, both the Attorneys Amendment Act (1993a) and the Admission of Advocates Amendment Act (1994b) failed to address the language question in the then 'new' dispensation. The legislature thought it neutral to removal all language requirements, but, by doing so, they maintained the status quo of the language of proceedings and record, namely English and Afrikaans. There was then no need or incentive for LLB graduates to acquire an African language before admission to the Side Bar or Bar. Thus, there was no onus upon universities to graduate bilingual or multilingual LLB students. 


\section{A transformed legal profession: Legal Practice Act}

Thus far, we have established that the language of proceedings and record must be determined by the legislature through legislative and policy means, in accordance with the SOP doctrine. Having said that, courts are creatures of statute, and the legislature, in regulating the functioning of courts, must have due regard for the constitutional provisions. The legislation we have advanced thus far, pertaining to South Africa, is illustrative of the legislature's failure to incorporate African language requirements in accordance with Section 6 of the Constitution, and provide for the equal application of the rights in Section 35 of the Constitution. As Cowling (2007:94) points out, the legislature has a responsibility to amend and enact legislation, reversing the discrimination and marginalisation endured during Apartheid. This requires vigorous change with the aim of achieving inclusivity for all. In heeding this call, the legal system embarked on a new transformed path, with the incremental introduction of the Legal Practice Act 28 of 2014.

The Legal Practice Act (2014), unfortunately, makes no mention of language and the language question in courts. In substantiating this statement, we advance extracts from the Legal Practice Act (2014) to illustrate this absence where language, in our opinion, should have been included. The purpose of the Legal Practice Act (2014) is:

To provide a legislative framework for the transformation and restructuring of the legal profession in line with constitutional imperatives to facilitate and enhance an independent legal profession that broadly reflects the diversity and demographics of the Republic...

From the extract, the phrases "... constitutional imperatives..." and "... reflects the diversity and demographics of the Republic..." refer to the inclusion of language, specifically the African languages. Section 3 of the Legal Practice outlines the purpose with more specificity:

3(a) provide a legislative framework for the transformation and restructuring of the legal profession that embraces the values underpinning the Constitution and ensures the rule of law is upheld;

(b)(iii) measures that provide equal opportunities for all aspirant legal practitioners in order to have a legal profession that broadly reflects the demographics of the Republic; ;..

Subsection b(iii), in our opinion, should include language as a measure that would enable equal opportunities for legal practitioners, given that the majority of persons in South Africa speak an African language as their mother tongue. This is not the case, upon further examination of the provisions: this includes Section 24, regulating the admission and enrolment to the legal profession. Subsection (2)(a) refers to a duly qualified person, as set out in Section 26 of the Legal Practice Act (2014). Section 26, regulating the minimum qualifications and practical vocational training, prescribes no language requirements for attorneys, candidate attorneys, advocates, or pupils. Furthermore, Section 29 of the Legal 
Practice Act (2014) governs community service, which will need to be undertaken for graduates to be admitted to the legal profession. Community service, to our understanding, would involve the small claims court or pro bono public interest law, and therefore involve communicating in some, if not most, instances with African language speakers. It is our opinion that these provisions should have included language requirements or language training programmes. This would have filled the language requirements gap in the Attorneys Amendment Act (1993a) and the Admission of Advocates Amendment Act (1994b).

\section{Legal professionals: racial demographics}

It is all well and good to propose provincial language policies for courts; however, it is meaningless if the legal professionals' language demographics do not correlate with language demographics of the country, presented in Part Two of Chapter 6. This again links to the role of university language policies (discussed in Chapter 9) and broader educational policies in shaping the linguistic trends of students at an early age prior to their entering the profession. Across the county, as far as we are aware, there has been no official or unofficial release of language competencies for legal professionals, including for judicial officers. In the case law presented in Chapter 7, we saw certain judges making enquiries with the relevant DPP authorities as to the linguistic proficiencies of state advocates (prosecutors). We elaborate upon this point in Chapter 10 as part of the conclusions and recommendations. That being said, the statistics at present pertain primarily to race and gender and, in a way, emulate the provisions of Section 174 of the Constitution in identifying only race and gender to the exclusion of language.

The reason that we have included these racial statistics of South Africa's legal professionals is that, in the State v Damani (2016), State v Gordon (2018), and UFS (2016; 2018) cases, amongst others, the judges have reverted to these statistics. There is a constant linkage in South Africa between race and language. This is not confined to South Africa, as we have seen in Australia, and in India where the caste system impacts the legal profession and access to justice. The thinking of racialising our languages must be excluded to build a united and inclusive society where languages are seen as the languages of all South Africans. The racial statistics pertaining to practising attorneys and advocates are housed in Tables 8.1 and 8.2. In Table 8.1, the Cape Law Society, the Free State Law Society and the Law Society of the Northern Provinces comprise a majority of White practising attorneys. 
TABLE 8.1 Racial demographics of the practicing attorneys per law society from April 2014 to April 2015 (Law Society of South Africa, 2015:34-43)

\begin{tabular}{|c|c|c|c|c|}
\hline Race & $\begin{array}{l}\text { Cape Law } \\
\text { Society }\end{array}$ & $\begin{array}{l}\text { Free State } \\
\text { Law Society }\end{array}$ & $\begin{array}{c}\text { Law Society of } \\
\text { The Northern } \\
\text { Provinces }\end{array}$ & $\begin{array}{l}\text { KwaZulu-Natal } \\
\text { Law Society }\end{array}$ \\
\hline African & 919 & 214 & 3586 & 617 \\
\hline Coloured & 1016 & 14 & 129 & 41 \\
\hline Indian/Asian & 216 & 4 & 652 & 1257 \\
\hline White & 4320 & 817 & 8381 & 1176 \\
\hline Unknown & 39 & 6 & 312 & 1 \\
\hline
\end{tabular}

TABLE 8.2 Racial demographics of the practicing advocates per Bar recoded in April 2014 (Law Society of South Africa, 2015:49)

\begin{tabular}{lc|c|c|c|}
\hline Bars & African & Coloured & Indian/Asian & White \\
Cape & 15 & 60 & 12 & 365 \\
\hline Port Elizabeth & 6 & 6 & 2 & 54 \\
\hline Grahamstown & 4 & 2 & 1 & 20 \\
\hline Free State & 7 & 1 & 0 & 60 \\
\hline Northern Cape & 2 & 0 & 1 & 8 \\
\hline Johannesburg & 251 & 21 & 65 & 664 \\
\hline Pretoria & 104 & 3 & 9 & 454 \\
\hline KwaZulu-Natal & 49 & 5 & 97 & 157 \\
\hline North West & 7 & 0 & 0 & 12 \\
\hline Transkei & 26 & 1 & 0 & 1 \\
\hline Bisho & 11 & 2 & 0 & 6 \\
\hline
\end{tabular}

The KwaZulu-Natal Law Society is the only law society in which the majority of practising attorneys are not White - the overwhelming majority of practising attorneys across the various provinces are White. A similar situation exists for advocates, as captured in Table 8.2. There is an overwhelming majority of White advocates at each bar with the exception of the Transkei and Bhisho bars in the Eastern Cape. For purposes of drafting and enacting provincial language policies for courts, in line with the recommendations in Chapter 10, the Law Society and General Council of the Bar would need to assess, against these statistics, in what languages these legal professionals are able to speak, read and write and at what level. Table 8.3 pertains to the racial demographics of the judges per division in the various provinces. 
TABLE 8.3 Racial demographics of High Court judges per division in each province, as at April 2015 (Law Society of South Africa, 2015:50)

\begin{tabular}{|c|c|c|c|c|}
\hline Divisions & African & Coloured & Indian & White \\
\hline $\begin{array}{l}\text { Constitutional Court } \\
\text { (Johannesburg) }\end{array}$ & 7 & 0 & 0 & 3 \\
\hline $\begin{array}{l}\text { Supreme Court of Appeal } \\
\text { (Bloemfontein) }\end{array}$ & 10 & 2 & 5 & 6 \\
\hline Northern Cape (Kimberley) & 4 & 1 & 0 & 2 \\
\hline Eastern Cape (Grahamstown) & 4 & 1 & 0 & 4 \\
\hline $\begin{array}{l}\text { Eastern Cape Local Division } \\
\text { (Port Elizabeth) }\end{array}$ & 2 & 0 & 1 & 4 \\
\hline $\begin{array}{l}\text { Eastern Cape Local Division } \\
\text { (Bisho) }\end{array}$ & 0 & O & 0 & 3 \\
\hline $\begin{array}{l}\text { Eastern Cape Local Division } \\
\text { (Mthatha) }\end{array}$ & 4 & & 1 & 2 \\
\hline $\begin{array}{l}\text { Western Cape Division (Cape } \\
\text { Town) }\end{array}$ & 8 & 11 & 2 & 12 \\
\hline North West (Mafikeng) & 3 & 1 & 1 & 1 \\
\hline $\begin{array}{l}\text { Free State Division } \\
\text { (Bloemfontein) }\end{array}$ & 5 & 1 & & 5 \\
\hline Gauteng Division (Pretoria) & 27 & 2 & 2 & 19 \\
\hline Gauteng Division (Gauteng) & 14 & 2 & 3 & 12 \\
\hline $\begin{array}{l}\text { KwaZulu-Natal Division } \\
\text { (Pietermaritzburg) }\end{array}$ & 7 & 1 & 3 & 5 \\
\hline $\begin{array}{l}\text { KwaZulu-Natal Local Division } \\
\text { (Durban) }\end{array}$ & 5 & 2 & 4 & 2 \\
\hline Labour Court & 3 & & & 7 \\
\hline
\end{tabular}

The demographics appears to be racially representative of the Republic's demographics. However, as we stated previously, in accordance with our recommendations in Chapter 10, a study will have to be undertaken to determine the linguistic competency of the judges, regardless of race, and ensure that this is representative of the language demographics across provinces. The racial statistics of magistrates in South Africa is presented in the table below. 
TABLE 8.4 Racial statistics of magistrates in South Africa, as on April 2015 (Law Society of South Africa, 2015:2)

\begin{tabular}{lc|c|c|c|}
\hline Magisterial Level & African & Coloured & Indian & White \\
\cline { 2 - 5 } Regional Court President & 7 & 1 & 0 & 1 \\
\cline { 2 - 5 } Regional Magistrate & 147 & 23 & 32 & 132 \\
\hline Chief Magistrate & 9 & 2 & 3 & 4 \\
\hline $\begin{array}{l}\text { Senior Magistrate } \\
\text { Magistrate }\end{array}$ & 37 & 6 & 4 & 31 \\
\hline
\end{tabular}

The racial equitability among Magistrates in South Africa is evident from the statistics in Table 8.4. The linguistic competency of magistrates is ever more urgent and necessary given that the magistrates are presiding officers in the lower courts which are courts of first instance. The majority of these magistrates deal with criminal law cases that involve African language and Afrikaans speaking accused persons, who would not be in a position to fully realise their Section 35(3) (k) right if the Magistrate can only speak English. In almost all the cases we have advanced in Chapter 7, the magistrates grappled with the language of record, with interpretational errors and inconveniences that amounted to grave injustices for both the accused persons and complainants.

\section{Attorneys' views on languages other than English}

Although the legislature has the mandate of legislating language requirements for legal professionals, it is important to gauge the views of legal practitioners on multilingualism and the use of languages other than English in the legal system. This speaks to the point advanced earlier, where Alexander (1997) promoted a bottom-up, rather than a top-down, approach to language planning. The latter most often results in resistance during the policy implementation stage.

De Vries and Docrat (2019) conducted such a survey; however, they focused solely on the attorneys' profession. Participation in the survey was voluntary. This should possibly be revised when another survey is undertaken by the state or legislature, as participation should be mandatory. According to De Vries and Docrat (2019:96), approximately 25,900 attorneys are registered with the Law Society in South Africa. Of these, 2,157 completed a computerised self-administered survey that essentially investigated issues that were regarded as important. The first section of the questionnaire comprised biographical questions focusing on aspects such as gender, age, provincial location in South Africa, undergraduate legal qualification and institution(s) of study. Questions excluded race. In the second section, participants answered questions about language ability, their use of two official South African languages in which they were fluent, as well as the languages used most often, and then secondarily most often, in these contexts: at home; in their social 
circles; during written and oral communication with clients and during communication with colleagues.

Participants were also asked about these aspects: the language in which they mostly conducted their research; the language of documentation and correspondence with clients, courts and opponents; the language of legal training; the practitioner's competence in English; as well as their clients' competence in English (as evaluated by practitioners). The final section of the questionnaire included 18 Likert-scale questions on practitioners' language attitudes, needs and choices. There were four response options for the Likert-scale questions, where the value of 1 indicated that the participant strongly disagreed with the applicable statement, while a value of 4 indicated that the participant strongly supported the applicable statement.

TABLE 8.5 Clients' English proficiency: The legal practitioners' perspective (De Vries \& Docrat, 2019:98)

\begin{tabular}{|l|c|c|}
\hline Proficiency in reading and writing & N $=1915$ \\
\hline Measured average & $2.16 / 3$ & 401 \\
Reasonable & 20.94 & 801 \\
Good & 41.83 & 713 \\
Excellent & 37.23 & $\mathrm{~N}=1915$ \\
\hline Proficiency in oral communication & 100 & 378 \\
\hline Measured average & $2.15 / 3$ & 870 \\
Reasonable & 19.74 & 667 \\
Good & 45.43 & \\
\hline Excellent & 34.83 & \\
\hline N $=$ total number of participants answering this question & \\
\hline
\end{tabular}

TABLE 8.6 Survey results: Attorneys' language attitudes, needs and choices (De Vries \& Docrat, 2019:100)

\section{Legend:}

1=Strongly disagree; 2=Disagree; 3=Agree; 4=Strongly Agree

The highlighted percentage under "Total" is a "measured mean".

The general language of use in the legal profession should be English.

\begin{tabular}{|c|c|c|c|c|c|}
\hline & 1 & 2 & 3 & 4 & Total \\
\hline No. & 443 & 196 & 320 & 821 & 1780 \\
\hline$\%$ & 24.89 & 11.01 & 17.98 & 46.12 & 2.85 \\
\hline
\end{tabular}


TABLE 8.6 Survey results: Attorneys' language attitudes, needs and choices (De Vries \& Docrat, 2019:100) [continued]

\begin{tabular}{|c|c|c|c|c|c|c|}
\hline $\begin{array}{l}\text { Legend: } \\
\text { 1=Strongly disagree; } 2=\mathrm{Di} \\
\text { The highlighted percenta }\end{array}$ & agree & "Agref & $\begin{array}{l}4 \text { = Stro } \\
\text { s a "me }\end{array}$ & igly Ag & ean". & \\
\hline \multirow{3}{*}{$\begin{array}{l}\text { Transformation in the } \\
\text { judicial system is fair. }\end{array}$} & & 1 & 2 & 3 & 4 & Total \\
\hline & No. & 419 & 468 & 481 & 399 & 1767 \\
\hline & $\%$ & 23.71 & 26.49 & 27.22 & 22.58 & 2.49 \\
\hline \multirow{3}{*}{$\begin{array}{l}\text { Transformation in } \\
\text { the judicial system } \\
\text { takes place at a } \\
\text { satisfactory rate. }\end{array}$} & & 1 & 2 & 3 & 4 & Total \\
\hline & No. & 345 & 498 & 563 & 358 & 1764 \\
\hline & $\%$ & 19.56 & 28.23 & 31.92 & 20.29 & 2.53 \\
\hline \multirow{3}{*}{$\begin{array}{l}\text { The judicial system } \\
\text { cannot transform } \\
\text { adequately if } \\
\text { multilingualism is sought }\end{array}$} & & 1 & 2 & 3 & 4 & Total \\
\hline & No. & 684 & 397 & 324 & 367 & 1772 \\
\hline & $\%$ & 38.60 & 22.40 & 18.28 & 20.71 & 2.21 \\
\hline \multirow{3}{*}{$\begin{array}{l}\text { It is in the best interests } \\
\text { of the client to consult } \\
\text { with him/her in English. }\end{array}$} & & 1 & 2 & 3 & 4 & Total \\
\hline & No. & 760 & 441 & 291 & 278 & 1770 \\
\hline & $\%$ & 42.94 & 24.92 & 16.44 & 15.71 & 2.05 \\
\hline \multirow{3}{*}{$\begin{array}{l}\text { It is in the best interests } \\
\text { of the client to consult } \\
\text { with him/her in his/her } \\
\text { home language. }\end{array}$} & & 1 & 2 & 3 & 4 & Total \\
\hline & No. & 180 & 257 & 365 & 970 & 1772 \\
\hline & $\%$ & 10.16 & 14.50 & 20.60 & 54.74 & 3.2 \\
\hline \multirow{3}{*}{$\begin{array}{l}\text { I have experienced } \\
\text { communication problems } \\
\text { with clients before } \\
\text { because we did not } \\
\text { properly understand each } \\
\text { other's language. }\end{array}$} & & 1 & 2 & 3 & 4 & Total \\
\hline & No. & 469 & 354 & 410 & 538 & 1771 \\
\hline & $\%$ & 26.48 & 19.99 & 23.15 & 30.38 & 2.57 \\
\hline \multirow{3}{*}{$\begin{array}{l}\text { I had to translate legal } \\
\text { documents from another } \\
\text { language into English } \\
\text { before. }\end{array}$} & & 1 & 2 & 3 & 4 & Total \\
\hline & No. & 798 & 221 & 256 & 490 & 1765 \\
\hline & $\%$ & 45.21 & 12.52 & 14.50 & 27.76 & 2.25 \\
\hline \multirow{3}{*}{$\begin{array}{l}\text { The translation of legal } \\
\text { documents can influence } \\
\text { the speed at which a case } \\
\text { is settled. }\end{array}$} & & 1 & 2 & 3 & 4 & Total \\
\hline & No. & 173 & 223 & 415 & 952 & 1763 \\
\hline & $\%$ & 9.81 & 12.65 & 23.54 & 54.00 & 3.22 \\
\hline \multirow{3}{*}{$\begin{array}{l}\text { Multilingualism can create } \\
\text { confusion in the legal } \\
\text { profession. }\end{array}$} & & 1 & 2 & 3 & 4 & Total \\
\hline & No. & 365 & 270 & 344 & 787 & 1766 \\
\hline & $\%$ & 20.67 & 15.29 & 19.48 & 44.56 & 2.88 \\
\hline \multirow{3}{*}{$\begin{array}{l}\text { In a multilingual country, } \\
\text { multilingualism in the } \\
\text { courts should be a given. }\end{array}$} & & 1 & 2 & 3 & 4 & Total \\
\hline & No. & 496 & 401 & 372 & 486 & 1755 \\
\hline & $\%$ & 28.26 & 22.85 & 21.20 & 27.69 & 2.48 \\
\hline
\end{tabular}


TABLE 8.6 Survey results: Attorneys' language attitudes, needs and choices (De Vries \& Docrat, 2019:100) [continued]

\begin{tabular}{|c|c|c|c|c|c|c|}
\hline $\begin{array}{l}\text { Legend: } \\
\text { 1=Strongly disagree; } 2=\mathrm{D} \\
\text { The highlighted percenta }\end{array}$ & agree & $\begin{array}{l}3=\text { Agre } \\
\text { "Tota }\end{array}$ & $\begin{array}{l}4=\operatorname{Strc} \\
\text { is a " } m \text { t }\end{array}$ & igly Agr & ean". & \\
\hline It can be confusing to & & 1 & $\overline{2}$ & 3 & 4 & Total \\
\hline $\begin{array}{l}\text { the client if an attorney } \\
\text { does not litigate in his/her }\end{array}$ & No. & 378 & 367 & 463 & 558 & 1766 \\
\hline home language. & $\%$ & 21.40 & 20.78 & 26.22 & 31.60 & 2.68 \\
\hline I regularly use language & & 1 & 2 & 3 & 4 & Total \\
\hline practitioners to translate & No. & 1208 & 310 & 110 & 133 & 1761 \\
\hline legal documents. & $\%$ & 68.60 & 17.60 & 6.25 & 7.55 & 1.53 \\
\hline & & 1 & 2 & 3 & 4 & Total \\
\hline I regularly use translators & No. & 650 & 344 & 325 & 422 & 1741 \\
\hline & $\%$ & 37.33 & 19.76 & 18.67 & 24.24 & 2.3 \\
\hline In a criminal case it is fair & & 1 & 2 & 3 & 4 & Total \\
\hline that a victim should pay & No. & 1279 & 188 & 96 & 185 & 1748 \\
\hline $\begin{array}{l}\text { for translation services } \\
\text { himself if he/she cannot } \\
\text { make a statement in } \\
\text { English. }\end{array}$ & $\%$ & 73.17 & 10.76 & 5.49 & 10.58 & 1.53 \\
\hline I have experienced & & 1 & 2 & 3 & 4 & Total \\
\hline before that interpreters' & No. & 288 & 356 & 486 & 605 & 1735 \\
\hline $\begin{array}{l}\text { translations cause } \\
\text { confusion during court } \\
\text { proceedings. }\end{array}$ & $\%$ & 16.60 & 20.52 & 28.01 & 34.87 & 2.81 \\
\hline & & 1 & 2 & 3 & 4 & Total \\
\hline benefit from learning & No. & 325 & 183 & 382 & 876 & 1766 \\
\hline $\begin{array}{l}\text { another indigenous South } \\
\text { African language. }\end{array}$ & $\%$ & 18.40 & 10.36 & 21.63 & 49.60 & 3.02 \\
\hline & & 1 & 2 & 3 & 4 & Total \\
\hline $\begin{array}{l}\text { Durıng the translation } \\
\text { process, I found that legal }\end{array}$ & No. & 252 & 390 & 494 & 596 & 1732 \\
\hline $\begin{array}{l}\text { concepts could not be } \\
\text { translated meaningfully } \\
\text { and in context in } \\
\text { other languages. }\end{array}$ & $\%$ & 14.55 & 22.52 & 28.52 & 34.41 & 2.83 \\
\hline
\end{tabular}


Table 8.5 illustrates that attorneys view the English language proficiency of clients as mainly 'good' and 'excellent'. This is contrary to the findings of the language survey by Legal Aid (2017); it also illustrates that some legal practitioners are somewhat oblivious to their clients' language difficulties. This was also the case in India, Morocco, Nigeria and Kenya, where the focus is on legal practitioners understanding the language, regardless of the client's language limitations. Table 8.6 presents mixed views on the importance of multilingualism and acknowledging this; responses show that there was disagreement among respondents about the importance of using other languages, with their cited reasons including difficulty in the translation process, time constraints involving translation, as well as costs for translation.

\section{Conclusion}

The discussions in this chapter illustrate that a transformational agenda is being implemented but, as with Section 174 of the Constitution, the Legal Practice Act (2014) excludes language as part of this agenda. That being said, the statistics in terms of racial demographics can be used in motivating for legislative language requirements for legal practitioners and judicial officers. However, as the discussions suggest, the starting point is with the education system and the LLB curriculum. 